\title{
Development and Analysis of Human Biodynamic Model Seated on a Driver Seat Exposure to Whole-Body Vibration
}

\author{
G. B. Kamalakar, A. C. Mitra \\ (Department of Mechanical Engineering, M.E.S. College of Engineering, Pune, S.P. Pune University, India)
}

\begin{abstract}
Many people daily exposes to noise and vibration generated environment, while travelling and working places. Generally many drivers of the heavy duty vehicles like tractors and trucks exposes to high level of Vibration in their occupational lives which causes vibration-induced injuries or disorders. A biodynamic model of seated posture human body developed which consists of an interconnected masses, springs and dampers. In this study the vibration effect on the each part of seated human body was analyse by constructing and simulating mathematical model in MATLAB-SIMULINK Software, and hence vibration effect on the seated human was analysed. Vibration are harmful if the level of vibration are more than the acceptable range. To avoid the harmful heath effect due to vibration first thing to avoid continues vibration exposure and second is reducing the vibration level. The RMS Values of displacement and acceleration was investigated to know maximum to minimum vibration effect on human body. The whole-body vibration exposure to seated human validated by MATLAB-SIMULINK simulation with state space model (Analytical Solution).
\end{abstract}

Keywords-State space equation, Whole-body vibration, Human body model, MATLAB-SIMULINK, Comfort, Biodynamic modes.

\section{INTRODUCTION}

The whole-body vibration (WBV) defined as the vibration forces transmitted to the whole body through supported vibrated surface. Generally while traveling vehicle driver's as well as sitting position passengers exposes to high level of machines vibration causes different type of health effects like muscle weakness, loss the sensitivity of skin, and heavy pain in the different organs.Piotr kowalski and Jacek zajac experiments on vibration tests of 30 most common means of in-house transport [2]. The ride quality of any new transportation system is depending on the level of vibrations which passengers are exposed. M.Z. Nuawi et al. Validated the travelling passengers exposed to vibration with daily exposure to vibration $A(8)$ values and vibration dose value (VDV)[5]. To assist the development of these new systems, study of the vibration effect on passengers becomes increasingly important. If the vehicle vibration are more than acceptable range the riding comfort will reduce. Marilu Figueiredo and Luiz Felipe shown by nalyzing Drivers are exposed to vibration levels above the recommended limits, then passengers suffers uncomfortable situation[11]. B. Cvetanovic and D. Zlatkovic investigated the engine generated vibrations exposed to tractor driver's body cause serious health issues[18]. In this study, biodynamic model of human in the seated position was developed for the analysis of vibration impact behaviour on the human body. Each part of the human body was considered as the masses which are joined with the spring and damper. Springs and damper connects the two masses indicates the motion transmitted and body displaces linearly. In this paper the model constructed with four masses, four springs and four damping constant as shown in the table no. 1. To investigate the displacement of the body part due to the vibration forces was investigated by MATLAB-SIMULINK Software. The mathematical linear equations were derived from the spring-mass-damper model. The 4-DOF MATLAB-SIMULINK Model was developed using coding based on the equation of motion.

\section{MATHEMATICAL MODELING}

The proposed model is a lumped-parameter linear spring, mass and damper system considering the human seated on a vehicle seat as shown in Fig. 1(a). The mathematical model developed from the side view of the seated human as shown in Fig. 1(b). The human body part more affected at the contacted area of human and the vibrating body like thigh and upper torso. The vibrations from feet are neglected because the variations between feet touching to the floor are not same for each person. The model includes segments representing appropriate anatomical parts of the human body and is capable of accommodating translational movements. Each body segments are considered as the spring-mass-damper form as shown in Fig. 2.

In the 4-DOF model, the main seated human body masses $(\mathrm{m} 0, \mathrm{~m} 1, \mathrm{~m} 2, \mathrm{~m} 3, \mathrm{~m} 4)$ is treated as a single limped mass. This assumption is in agreement with the evidence that the contribution of the supported legs to 6th National Conference RDME 2017, 17th-18th March 2017. 
the WBV is relatively insignificant when both the seat and the footrest are vibrated under the same vibration excitations.

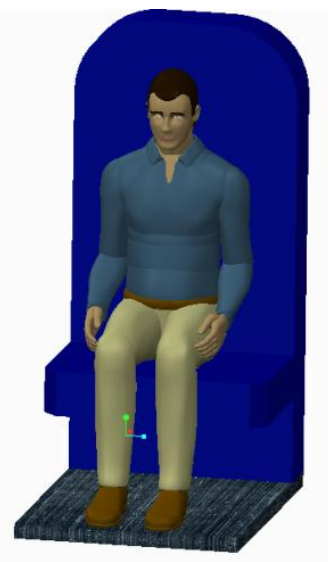

(a)

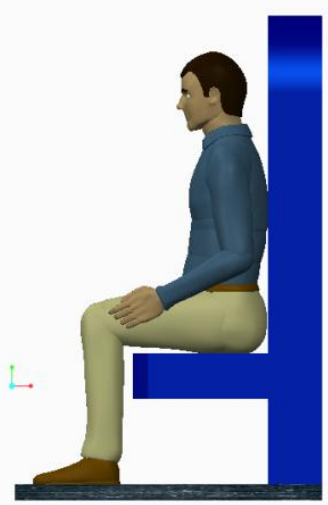

(b)

Fig. 1: (a) Human seated on a vehicle seat posture, (b) Human seated on a vehicle seat side view

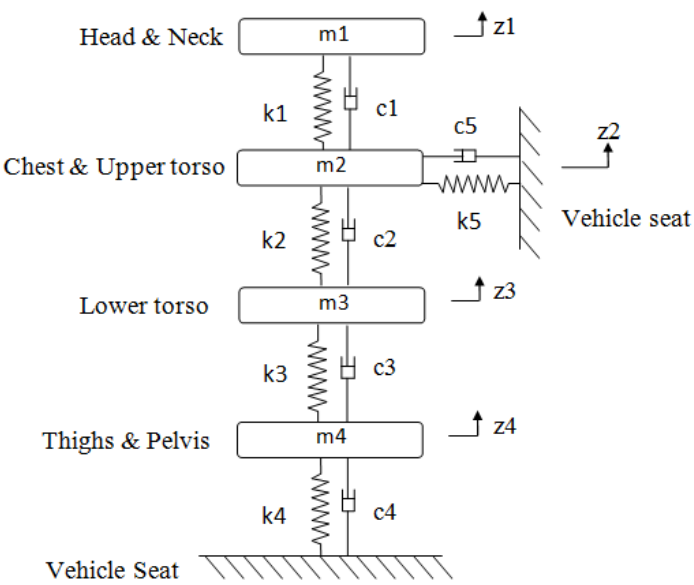

Fig. 2: Mathematical model for seated human subjects in vertical direction

\section{Equations of motion (EOMs)}

EOMs of the model were derived from the free-body diagram of each human body parts. The vertical model has five degrees of freedom in total, the vertical displacement of each part is $\left\{z_{1}, z_{2}, z_{a}, z_{4}, z_{5}\right\}$.

The vertical model EOMs can be expressed by the following coupled differential equations:

$$
\begin{aligned}
& m_{1} z_{1}+c_{1}\left(z_{1}^{*}-z_{2}^{0}\right)+k_{1}\left(z_{1}-z_{2}\right)=0 \\
& m_{2} z_{2}+c_{2}\left(z_{2}^{x}-z_{a}^{x}\right)+k_{2}\left(z_{2}-z_{a}\right)+c_{1}\left(z_{2}^{x}-z_{1}^{x}\right)+k_{1}\left(z_{2}-z_{1}\right)=0 \\
& m_{a} z_{a}+c_{2}\left(z_{a}-z_{2}^{c}\right)+k_{2}\left(z_{a}-z_{2}\right)+c_{a}\left(z_{a}^{x}-z_{4}^{c}\right)+k_{a}\left(z_{a}-z_{4}\right)=0 \\
& m_{4} z_{4}+c_{a}\left(z_{4}^{n}-z_{a}^{n}\right)+k_{a}\left(z_{4}-z_{a}\right)+c_{4} z_{4}^{0}+k_{4} z_{4}+F=0
\end{aligned}
$$

The differential equations are expressed in the form as,

$$
[\mathrm{m}]\{\mathrm{z}\}+[\mathrm{c}]\{z \mathrm{z}\}+[\mathrm{k}]\{\mathrm{z}\}=\{\mathrm{F}\}
$$

Where,

mass indicated by $[\mathrm{m}]$, damping constant indicated by $[\mathrm{c}]$ and stiffness constant indicated by [k] respectively; $\{z\},\{z\}$ and $\{z\}$ are acceleration, velocity and displacement vectors, respectively. 


\section{Model Parameter Identification}

Table no. 1: Parameter's values for the vertical seated human body models

\begin{tabular}{|l|l|}
\hline Model parameters & Values \\
\hline Head and neck mass $\mathrm{m}_{1}(\mathrm{~kg})$ & 10.12 \\
\hline Chest $\&$ Upper torso mass $\mathrm{m}_{2}(\mathrm{~kg})$ & 40.35 \\
\hline Lower torso mass $\mathrm{m}_{\mathrm{a}}(\mathrm{kg})$ & 15.36 \\
\hline Thigh \& upper torso mass $\mathrm{m}_{4}(\mathrm{~kg})$ & 25.81 \\
\hline Damping coefficient $\mathrm{c}_{1}(\mathrm{Ns} / \mathrm{m})$ & 620 \\
\hline Damping coefficient $\mathrm{c}_{2}(\mathrm{Ns} / \mathrm{m})$ & 8550 \\
\hline Damping coefficient $\mathrm{c}_{\mathrm{a}}(\mathrm{Ns} / \mathrm{m})$ & 5685 \\
\hline Damping coefficient $\mathrm{c}_{4}(\mathrm{Ns} / \mathrm{m})$ & 3564 \\
\hline Stiffness coefficient $\mathrm{k}_{1}(\mathrm{~N} / \mathrm{m})$ & 450000 \\
\hline Stiffness coefficient $\mathrm{k}_{2}(\mathrm{~N} / \mathrm{m})$ & 213000 \\
\hline Stiffness coefficient $\mathrm{k}_{\mathrm{a}}(\mathrm{N} / \mathrm{m})$ & 262800 \\
\hline Stiffness coefficient $\mathrm{k}_{4}(\mathrm{~N} / \mathrm{m})$ & 980000 \\
\hline
\end{tabular}

\section{ANALYTICAL SOLUTION (STATE SPACE MODEL)}

A state space model developed in MATLAB-SIMULINK Software by developing the by creating matrix from linear differential equations 5 to 8 .

The model of the system can be described in following differential equations as:

$$
\begin{aligned}
& z_{1}^{m}=-\frac{c_{1}}{m_{1}}\left(z_{1}^{x}-z_{2}^{x}\right)-\frac{k_{1}}{m_{1}}\left(z_{1}-z_{2}\right) \\
& \mathrm{z}_{2}=-\frac{\mathrm{c}_{2}}{\mathrm{~m}_{2}}\left(\mathrm{z}_{2}^{\infty}-\mathrm{z}_{\mathrm{a}}^{\mathrm{x}}\right)-\frac{\mathrm{k}_{2}}{\mathrm{~m}_{2}}\left(\mathrm{z}_{2}-\mathrm{z}_{\mathrm{a}}\right)-\frac{\mathrm{c}_{1}}{\mathrm{~m}_{2}}\left(\mathrm{z}_{2}^{\mathrm{x}}-\mathrm{z}_{1}^{\mathrm{x}}\right)-\frac{\mathrm{k}_{1}}{\mathrm{~m}_{2}}\left(\mathrm{z}_{2}-\mathrm{z}_{1}\right)
\end{aligned}
$$

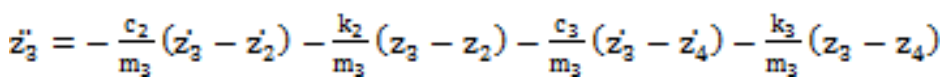

$$
\begin{aligned}
& \mathrm{z}_{4}=-\frac{\mathrm{c}_{3}}{\mathrm{~m}_{4}}\left(\mathrm{z}_{4}^{\mathrm{x}}-\mathrm{z}_{\mathrm{a}}^{\mathrm{x}}\right)-\frac{\mathrm{k}_{3}}{\mathrm{~m}_{4}}\left(\mathrm{z}_{4}-\mathrm{z}_{\mathrm{a}}\right)-\frac{\mathrm{c}_{4}}{\mathrm{~m}_{4}} \mathrm{z}_{4}^{\mathrm{x}}-\frac{\mathrm{k}_{4}}{\mathrm{~m}_{4}} \mathrm{z}_{4}+\frac{\mathrm{F}}{\mathrm{m}_{4}} \\
& \mathrm{z}_{1}, \mathrm{z}_{2}, \mathrm{z}_{\mathrm{a}}, \mathrm{z}_{4} \text { Position, } \\
& z_{1}^{x}, z_{2}, z_{2}^{x}, z_{4}^{x} \text { Speed/Velocity, } \\
& \mathrm{z}_{1}, \bar{z}_{2}, \bar{z}_{2}, \bar{z}_{4} \text { Acceleration. }
\end{aligned}
$$

Where,

The State-space model of spring-mass-damper model written as following general form equation as:

$\dot{\mathrm{x}}=\mathrm{Ax}+\mathrm{Bu}$

$\mathrm{y}=\mathrm{Cx}+\mathrm{Du}$

Define state-space model matrix for the system 


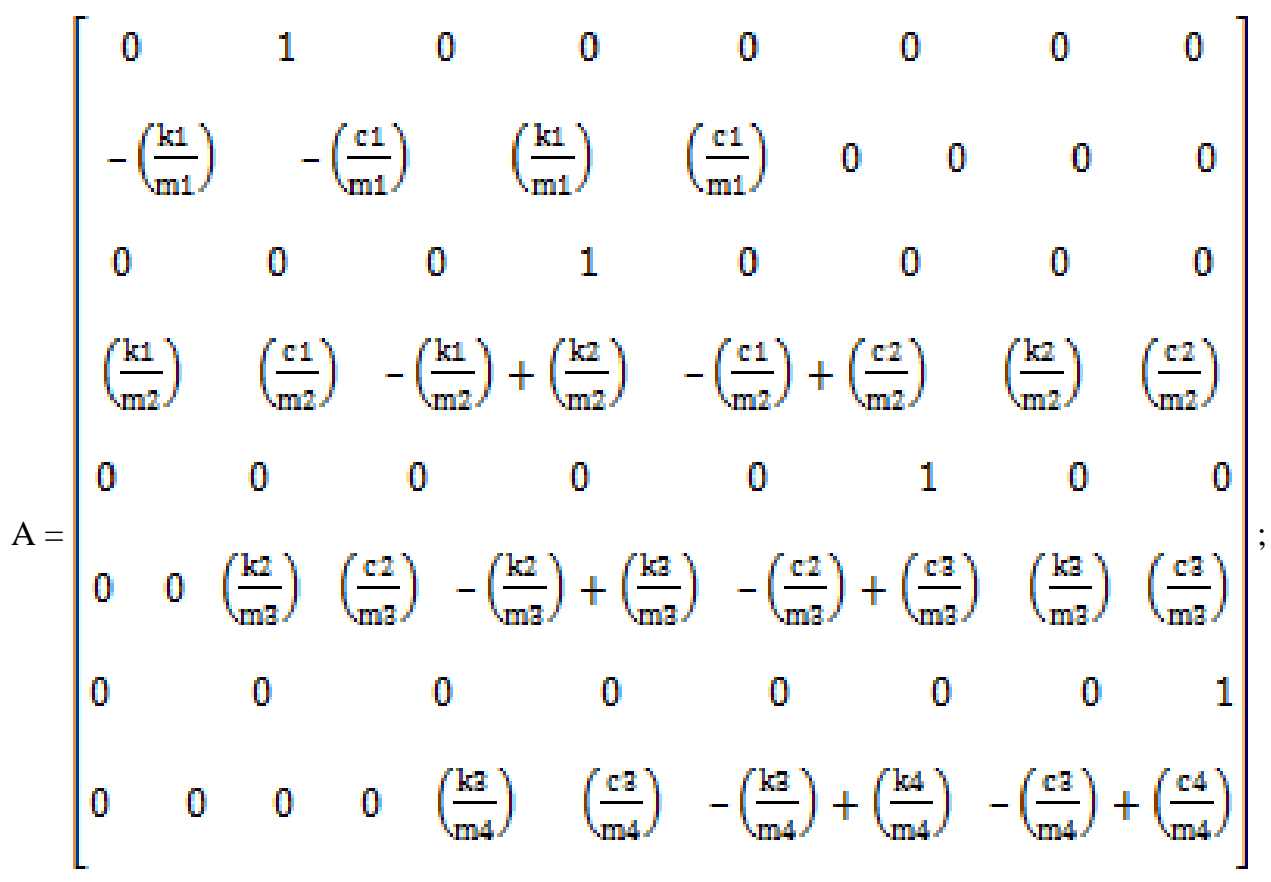

$$
\begin{aligned}
& B=\left[\begin{array}{c}
0 \\
0 \\
0 \\
0 \\
0 \\
0 \\
0 \\
1 / \mathrm{m} 4
\end{array}\right] \text {; }
\end{aligned}
$$

Putting the constants values in above matrix from Table no. 1 ,

$$
\mathrm{A}=\left[\begin{array}{ccccccccc}
0 & 1 & 0 & 0 & 0 & 0 & 0 & 0 \\
-8637 & -55.15 & 8637 & 55.15 & 0 & 0 & 0 & 0 \\
0 & 0 & 0 & 1 & 0 & 0 & 0 & 0 \\
3048 & 19.46 & -8314 & -215.6 & 5266 & 196.1 & 0 & 0 \\
0 & 0 & 0 & 0 & 0 & 1 & 0 & 0 \\
0 & 1.697 \mathrm{e}+004 & 632 & -3.733 \mathrm{e}+004 & -1143 & 2.036 \mathrm{e}+004 & 510.7 \\
0 & 0 & 0 & 0 & 0 & 0 & 0 & 1 \\
0 & 0 & 0 & 0 & 1.084 \mathrm{e}+004 & 272.1 & -2.881 \mathrm{e}+004 & -393.9
\end{array}\right]
$$$$
\mathrm{B}=\left[\begin{array}{c}
0 \\
0 \\
0 \\
0 \\
0 \\
0 \\
0 \\
0.038794
\end{array}\right] \text {; }
$$ 


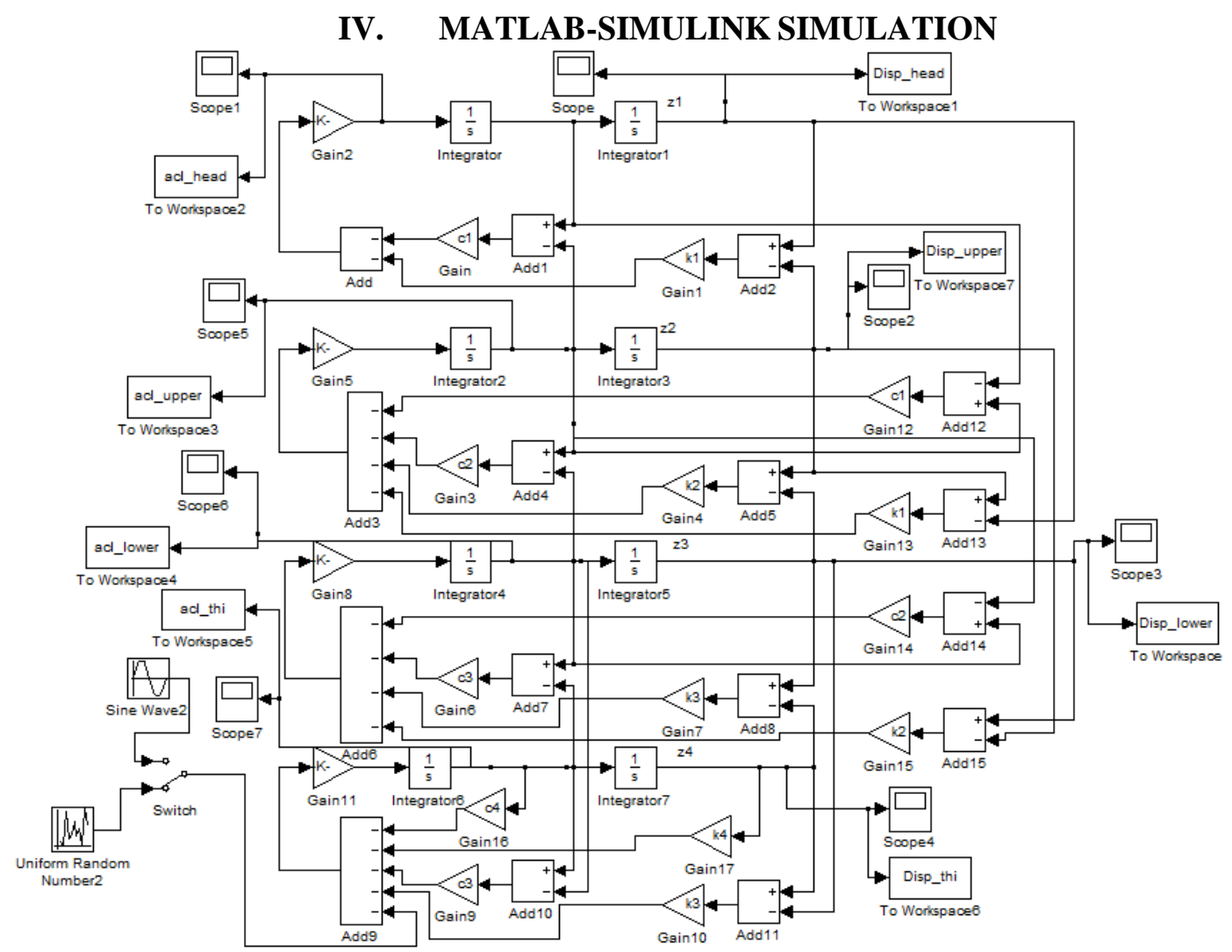

Fig. 3: SIMULINK model for seated human posture exposed to WBV

MATLAB-SIMULINK model developed on the basis of linear defferential equations 1 to 4 considering vibration forces absorbed by human body as shown in Fig. 3. The RMS values of displacement and acceleration calculted from SIMULINK model as shown Table 2.

\section{RESULTS AND DISCUSSIONS}

The study of vibration effect on the seated human on a vehicle seat was analysed. Vibration are harmful if the level of vibration are more than the acceptable range. Vibration affect the tissues, nerves, blood cells, skin layer which may loss the sensitivity of the organ as well as the pain in the muscles and bones. If the persons exposed to vibration daily prolonged time it may cause the improper working of the body organ which is more contacted with vibrated object. To avoid the harmful heath effect due to vibration first thing to avoid continues vibration exposure and second is reducing the vibration level.

In this study the vibration effect on the each part of seated human body was analyse by constructing and simulation of mathematical model in MAT-LAB SIMULINK Software.

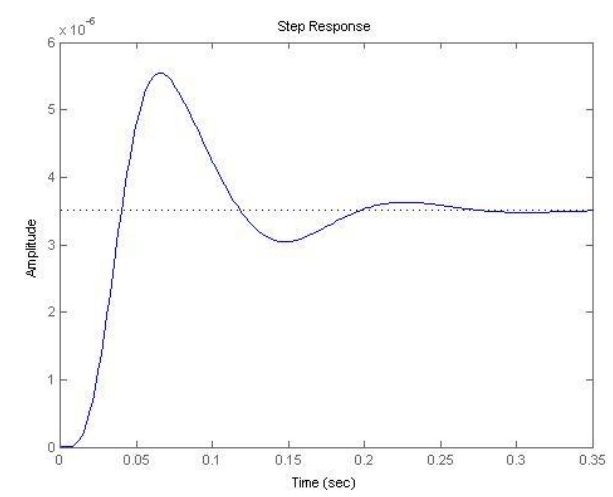

(a)

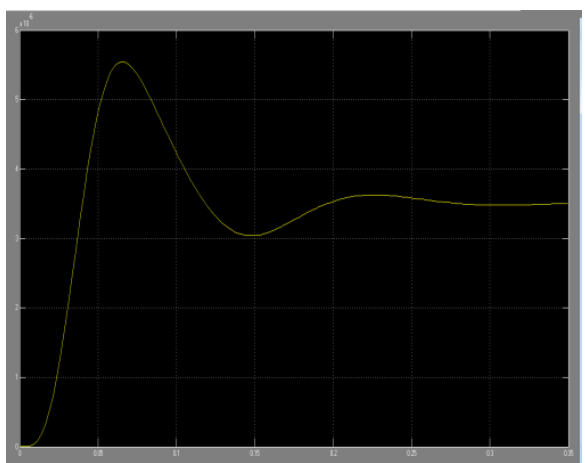

(b)

Fig. 4: Graph for Validation of seated human on a vehicle seat vibration exposure: (a) Graph obtained by State space equation (Analytical solution), (b) Graph obtained by MATLAB Simulation. 
The validation for vibration effect on seated human is represented by graph as shown above Fig. 4. The graph of amplitude Vs time shown in Fig.4(a) which is analatical solution of differential equation of mathematical model. The graph of displacement Vs time shown in Fig. 4(b) which is MATLAB-SIMULINK simulation output graph. Both the graph showing the same nature.

Table no. 2 : MATLAB-SIMULINK simulation result

\begin{tabular}{|l|l|l|l|}
\hline Input type & Parameters & $\begin{array}{l}\text { RMS Values Acceleration } \\
\left(\mathrm{m} / \mathrm{s}^{2}\right)\end{array}$ & RMS Values Displacement $(\mathrm{m})$ \\
\hline \multirow{5}{*}{ Step Input } & Head \& Neck & $2.497736 \mathrm{E}-05$ & $3.4599 \mathrm{E}-06$ \\
\cline { 2 - 4 } & Chest \& Upper torso & $3.75297 \mathrm{E}-05$ & $3.53301 \mathrm{E}-06$ \\
\cline { 2 - 4 } & Lower torso & $3.60037 \mathrm{E}-05$ & $3.49548 \mathrm{E}-06$ \\
\cline { 2 - 4 } & Thighs \& Pelvis & $3.80381 \mathrm{E}-05$ & $3.58796 \mathrm{E}-06$ \\
\hline
\end{tabular}

The Table no. 2 showing the RMS values of Acceleration and Displacement at different parts of the human body. The table shows the displacement value at thighs \& Pelvis is 3.8 (maximum) and acceleration value at the head is 2.49 (minimum). The table also showing the acceleration value at thighs $\&$ Pelvis is 3.8 (maximum) and acceleration value at the head is 2.49 (minimum), which means the vibration effect is more at contacted area of human body and vehicale .

\section{CONCLUSION}

The drivers of the heavy duty vehicles like tractors and trucks exposes to high level of Vibration in their occupational lives which causes vibration-induced injuries or disorders. The aim of this study is to evaluate response of seated posture spring-mass-damper system human body model exposure to Whole-BodyVibration. The seated human four Degree of Freedom(DOF) biodynamic model analysed and Simulatate in MATLAB-SIMULINK Software. The whole-body vibration exposure to human validated by MATLABSIMULINK simulation with state space model (Analytical Solution). The RMS Values of displacement and acceleration was investigated to know maximum to minimum vibration effect on human body.

\section{REFERENCES}

[1] F.L.Roberts.,W.R.Hudson., II Pavement Serviceability Equations Using the Surface Dynamics Profilometer, Centre for Highway Research, The University ty of Texas at Austin, Research Report 73-3, 1970.

[2] P. kowalski, J. zajac, Whole-Body and Hand-Arm Vibration in In-House Transport, Archies of acoustics 35, 2, 183-190, 2010

[3] H.C.Boshuizen.,P.M. Bongers, C.T.Hulshof, Self reported back pain in fork-lift truck and freight container tractor drivers exposed to whole-bodyvibration, pp. 59-65, 1992.

[4] Anonymous, A Guide to the Evaluation of Human Exposure to Whole Body Vibration, ISO/DIS 2631, International Organization for Standardization, New York, 1972.

[5] M.Z. Nuawi, A.R. Ismail , M.J.M. Nor and M.M. Rahman, A comparative study of whole-body vibration exposure in train and car passengers: A case study in malaysia, International Journal of Automotive and Mechanical Engineering (IJAME), 4, 2011,490-503.

[6] R.A.Lee, Pradko, F., IIAnalytical Analysis of Human Vibration, S.A.E. Transactlons 680091, 1968, $346-370$.

[7] A.A.Deshmukh, Assessment of whole body vibration among forklift drivers using ISO 2631-1 and ISO 2631-5, Department of Industrial and Manufacturing Engineering, Pune University, 2009.

[8] Anonymous, II Design Specifications for Urban Tracked Air Cushion Vehicles, U. S. Department of Transportation, Washington, D. C., 1972.

[9] R. N., Vehicle Vibration Limits to Fit he Passenger, S.A.E. J., 56, 1948, 48-49.

[10] Futatsuka M., Maeda S., Inaoka T., Nagano M., Shono M. and Miyakita T., Whole-body vibration and health effects in the agricultural machinery drivers, Ind Health,36(2), 1998, 12732.

[11] M. Alcântara de Melo Figueiredo, L. Felipe Silva, Public transport : whole body vibration and comfort of passengers, drivers and collectors, Natural Resources Institute, Federal University of Itajuba, ,37550-903 Itajuba, Brazil.

[12] A.J.Healey, Passenger Response to Random Vibration in Transportation Vehicles - A Literature Review, Research Report RR-30, Council for Advanced Transportation Studies, University of Texas, 1975.

[13] A.A.Butkunas., Power Spectral Density and Ride Evaluation, S.A.E. Transactions No. 660138, 1966, 681-687.

[14] M.J.Griffin, Handbook of human vibration(Academic Press, Harcourt Brace Jovanovich, London,1990)

[15] Cormie P,R.S. Deane ,N.T. Triplett, et al. Acute effects of whole body vibration on muscle activity, strength, and power, J Strength Cond Res,20(2),2006,257-61.

[16] A.M.Lis.,K.M.Black,H. Korn, M.Nordin, Association between sitting and occupational LBP, European Spine Journal, 16(2),283298.

[17] B. Basri, M.J. Griffin , Predicting discomfort from whole body vertical vibration when sitting with an Inclined backrest, Applied Ergonomics, 44,423-434.

[18] B. Cvetanovic and D. Zlatkovic, Evaluation of whole-body vibration risk in agricultural tractor drivers, Bulgarian Journal of Agricultural Science, Agricultural Academy, 2013, 1155-1160.

[19] E. Khorshid, F. Alkalby, H. Kamal , Measurement of whole body vibration exposure from speed control humps, Journal of Sound and Vibration, 304,640-659. 